\title{
LOOKING FOR STUDENTS' ENTHUSIASM: FLIPPED CLASSROOM
}

\author{
M. Soler ${ }^{1}$, M. Bentabol ${ }^{1}$, A.P. Lopes ${ }^{2}$, R. Caña ${ }^{1}$, A. Bentabol' ${ }^{1}$, M.M. Muñoz ${ }^{1}$, \\ A. Esteban ${ }^{1}$, M.J. Luna ${ }^{1}$, L. Cortés ${ }^{1}$ \\ ${ }^{1}$ Universidad de Málaga (SPAIN) \\ ${ }^{2}$ Polytechnic of Porto (PORTUGAL)
}

\begin{abstract}
The "flipped classroom" is a pedagogical model that consists of putting certain learning processes outside the classroom so that the teacher can devote more class time to students' acquisition of practical skills, for example. In this way, the teacher is not limited to the transmission of course content, but in addition assumes the role of a mediator in the cognitive process, allowing students to actively construct their own knowledge. In this role, the teacher's main task is to encourage students to become independent learners.

This paper describes the implementation and initial results of the application of the flipped classroom in higher education. This study is part of a larger research project to improve our students' motivation through the use of the flipped learning. The sample consisted of about 3000 students taking 17 different subjects, in Management and Administration Business, Finance and Accounting, Marketing and Market Research, and Chemistry, at the University of Málaga, and in Accounting and Administration, Business Communication and Marketing at the Polytechnic of Porto.

According to our results, students' motivation and class attendance increased with the application of this model; a comparison of the final exam results from two years with traditional classes and from two years with flipped learning shows that the proportion of students failing the exam decreased, which confirms that the use of this pedagogic model improves student learning.
\end{abstract}

Keywords: Flipped Classroom, motivation, innovation, Flipped Learning.

Acknowledgement:

This project is financed by Educational Innovation Projects 2017-2019 from Malaga University.

\section{INTRODUCTION}

In recent times, the "flipped classroom" or "inverted classroom", a pedagogical approach that focuses on student-centered learning much more than is done in the traditional classroom environment, has obtained attention and acceptance in higher educational institutions (HEls). This new model for organizing the educational process is a pedagogical inversion of the traditional teaching paradigm: the main elements of the teaching and learning process that are used in traditional classrooms are instead prepared by students before they come to class, so that they can engage with the content at a deeper level in the classroom [1], [2]. The flipped classroom model can be described as a set of theories, including constructivism, active learning, and peer-assisted learning [3]. This pedagogical approach may contain a large array of out-of-class activities, and in-class activities may include a wide range of approaches, such as role-play, debates, quizzes, and group presentations [4].

For the flipped classroom, the instructor becomes a guide and facilitator, indicating the way to go. As such, the instructor does not lead the way; that is, the instructor's role is to motivate students in their own knowledge construction, letting them lead the way, following and supporting, constantly and carefully monitoring their learning outcomes [5]. The instructor should try to use multiple approaches rather than one single approach, such as group discussion, mini-lectures for review, or "gamification" [6]. The gamification of education is interesting because it significantly increases students' motivation to learn [7], partly because it draws on students' familiarity with and enjoyment of digital entertainment technology [8]. The term is relatively new and refers to the "use of elements of game design in contexts not related to games" [9]. The concept is applicable in areas such as business as well as in education. "Gamification is using game-based mechanics, aesthetics and game thinking to engage people, motivate action, promote learning, and solve problems" [10]. The crucial aim of gamification applied to education is to increase students' motivation to achieve a certain goal through the addition in the learning system of components related to the mechanics of games. 
After many years of teaching in a university that was often crowded, a group of four professors at the University of Málaga (UMA) observed with concern the apathy and demotivation of their students. To try to correct this, in the 2015-2016 academic year they launched the Educational Innovation Project (PIE15 / 174), funded by the UMA. The project applied the "flipped classroom" pedagogical model to some subjects offered at the UMA.

They chose this methodology for the project because they intended to help students to take responsibility for their own learning. University students should be capable of being masters of their time and effort. The methodology involves "giving voice to students and allowing them to be the main actor of the class, which is gradually configured according to the same development that they require and propose" [11]. The integration of the flipped classroom into the educational process has previously been shown to lead to an increase of students' motivation and interest in their studies. It has a positive impact on students' determination and autonomy because students take responsibility for their own learning [5].

Because Spanish universities typically have many students per classroom, it is difficult to assess the progress of each student and their assimilation of new subject content. The flipped classroom can help to overcome this problem, as it can also be seen as "a framework that ensures that students receive a personalized education adapted to their individual needs" [1].

PIE15 / -174 proved a success. Therefore, more professors and subjects were integrated into the project, which continued as Educational Innovation Project PIE17- / 116. The main objectives of PIE17- / 116 were:

- Adapt the "flipped classroom" approach to the specific context of the UMA, and to each of the degree programs and subjects involved.

- Improve the educational techniques applied, in particular with a greater use of ICT and the use of resources such as Kahoot, Socrative, and other gamification tools.

- Encourage autonomous student learning.

- Enhance the ability of students to put what they've learned into practice.

- Increase students' academic performance.

- Adapt the evaluation system to the flipped classroom model.

At present, three faculties of the UMA and a school from the Polytechnic of Porto are involved in this project. They are: the Faculty of Economics and Business Studies, the Faculty of Commerce and Management, the Faculty of Sciences, and the Institute of Accounting and Administration of Porto (ISCAP). It has been applied in the following subjects and degree and masters programs: General Accounting; Management Accounting; Auditing; Administration and Business Management; Finance and Accounting; Marketing and Market Research in Management Accounting; Mathematics; Public Administration; Introduction to Accounting; Public Accounting; Chemistry (specifically, the Crystallography and Mineralogy course); Financial Mathematics; Mathematics Zero of Accounting and Administration; Business Communication and Marketing.

\section{METHODOLOGY}

The PIE15 / 174 initially involved more than 1,300 students in the different subjects and different institutions named above. PIE15- / 174 had a development phase, followed by the application of the model.

\subsection{Development phase}

- The professors involved were given training in this new methodology.

- The necessary resources had to be either found elsewhere or designed in-house. This included the selection and preparation of PowerPoint presentations and video lectures. We used Movie Maker and Camtasia Studio 8 software to record and edit lectures delivered in the Advanced Teaching Classrooms (ADA) of the Virtual Teaching Services at the UMA and ISCAP. We also used materials available on internet channels such as YouTube.

- These teaching materials were made available in the "Virtual Campus", where students could view them as many times as necessary, at their own pace and whenever it suited them, promoting the flexibility to learn at any time and any place. In addition, Kahoot software was employed. Kahoot is a Student Response System (SRS) that can be used to create multiplechoice questions, presented as a quiz, discussion or survey on a web platform. This 
gamification tool was used as a means for students to learn by responding to interactive questionnaires developed on the platform. We have therefore developed a question bank in the application.

\subsection{Introduction of the flipped classroom}

- On the first day of class, the foundations of the project (Fig. 1) were presented to the students as part of the schedule for the subject.

- During the class, the lecturer guided the types of group work shown in the middle column of Fig. 1.

\begin{tabular}{|l|l|l|}
\hline $\begin{array}{l}\text { BEFORE CLASS } \\
\text { Individual work }\end{array}$ & $\begin{array}{l}\text { DURING CLASS } \\
\text { Group work }\end{array}$ & $\begin{array}{l}\text { AFTER CLASS } \\
\text { Individual and group work }\end{array}$ \\
\hline $\begin{array}{l}\text { Viewing presentations or } \\
\text { videos of the contents of } \\
\text { the subject }\end{array}$ & - Application of knowledge & $\begin{array}{l}\text { Consolidation of content } \\
\text { through study or practice }\end{array}$ \\
& - Individual or group activities \\
& - Kahoot questionnaires \\
& - Computer classroom \\
& questionnaires & \\
\hline
\end{tabular}

Fig. 1: Scheme of work in the flipped classroom project

- At the end of each course, students were asked to complete a survey (online or in class) to assess their satisfaction with different aspects of the project. It was necessary to adapt the survey to each degree and subject, considering its own characteristics, number of hours of faceto-face teaching, degree of experimentally, course (1st, 2 nd, 3rd or 4 th), etc.

\subsection{Extension of the project}

The results obtained in PIE15-174 (applied during 2015-2016 and 2016-2017 years) showed the suitability of the flipped classroom methodology. The project was therefore extended, with the involvement of more lecturers and more students. Areas of deficiency noted in the initial project were addressed.

PIE17-116 was applied during the 2017-2018 academic year. The tasks were as follows:

- Preparation and improvement of teaching content in the UMA Virtual Campus and ISCAP. New teaching material was prepared for each of the subjects involved in the project, consisting mainly of videos and/or explanatory PowerPoint presentations, which subsequently were included in the Virtual Campus, allowing students to view them as many times as necessary before coming to class and working through the topic in the classroom.

- Preparation and revision of Kahoot questionnaires. For each subject, Kahoot questionnaires were either revised or newly prepared.

- Preparation of self-assessment questionnaires. A question bank has been developed through the quiz/test activity setting in Moodle. Students can thereby assess their own knowledge acquisition in each subject. Furthermore, professors can decide the most appropriate evaluation system for their own particular circumstances, in line with the objectives of autonomous learning and the encouragement of student participation.

- Preparation of questionnaires for knowledge tests. Questionnaires to test students' acquisition of the theoretical parts of course contents have been devised and presented as a Moodle test activity, as an alternative evaluation system to the final exam.

- Use of Kahoot as one of the methods for evaluating each student's active participation. Kahoot has been used to present questionnaires that allow students to assess, in a personalized way, their own degree of understanding of the main concepts of the topics studied; they also allow lecturers to assess the involvement of students in the methodology applied.

- Use of the Socrative application in classroom as an interaction tool. The Socrative classroom app allows students to show their difficulties in the classroom, and to perform gamification activities in the classroom. 
- Project satisfaction survey. An end-of-course survey assessed student satisfaction with the different aspects of the project. An evaluation of the data allowed us to identify and correct problems, make improvements, and strengthen further those points that work properly.

- Partial evaluation of academic results. Compared with previous years, student attendance and participation in class improved considerably, and there were also improvements in academic performance, as reported below.

\section{RESULTS}

The achievements of the project can be assessed from both the students' and teachers' point of view. The former assessment was through the student surveys done at the end of each semester.

\subsection{Results from the point of view of the students}

The student surveys included the five questions discussed below. Respondents were asked to rate each item on a scale of $1-5$, with higher scores reflecting more positive assessments.

\section{What is your overall assessment of the project?}

The students assessed the project positively: $49 \%$ gave it a rating of "good" and $35 \%$ "very good" (Fig. 2).

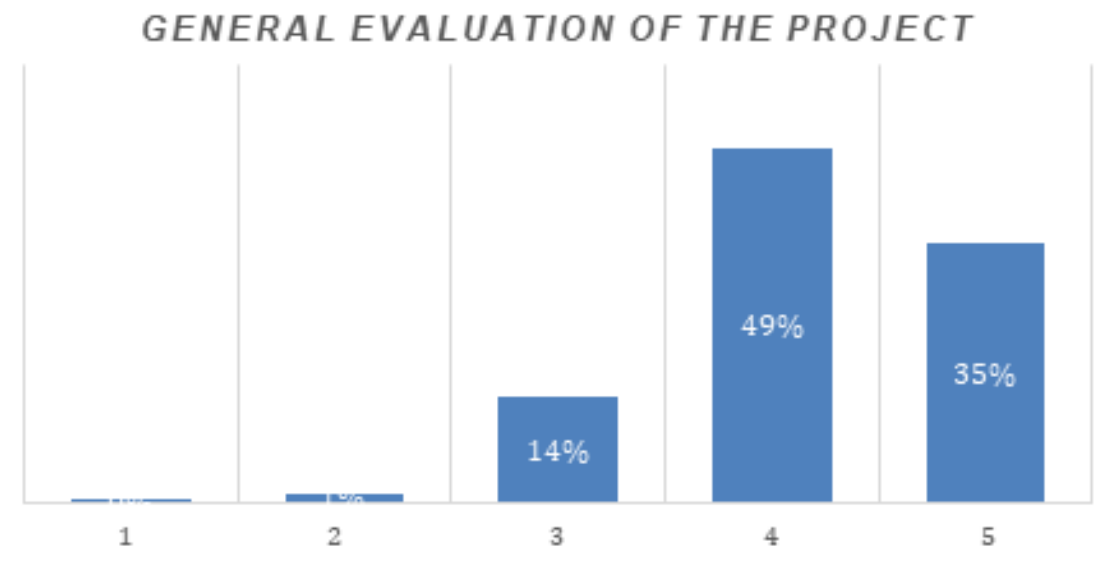

Fig. 2. Overall assessment of the project

2. Do you prefer the flipped classroom methodology to a traditional class, taught by the teacher?

More than $70 \%$ preferred the "flipped classroom" to a traditional class (Fig. 3). Likewise, almost $80 \%$ of the students surveyed indicated that they would like to be able to have a similar learning system for other subjects.

\section{FLIPPED CLASSROOM VERSUS \\ TRADITIONAL CLASS}

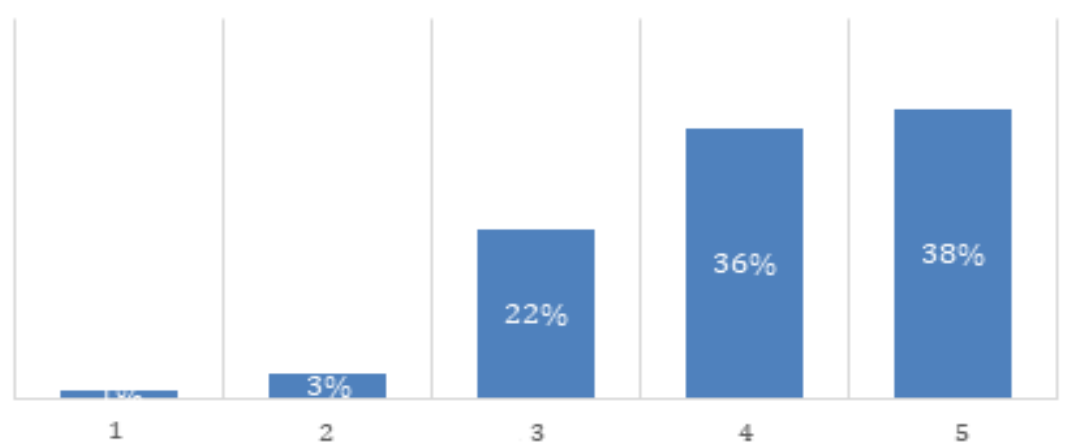

Fig.3. Preference of students for the two types of course delivery 
3. Do you think the flipped classroom has helped you to follow the subject better and not drop out?

Approximately $70 \%$ of students considered that this methodology helped them to follow the subject better and not drop out (Fig. 4).

\section{FOLLOW THE SUBJECT BETTER AND NOT}

DROP OUT

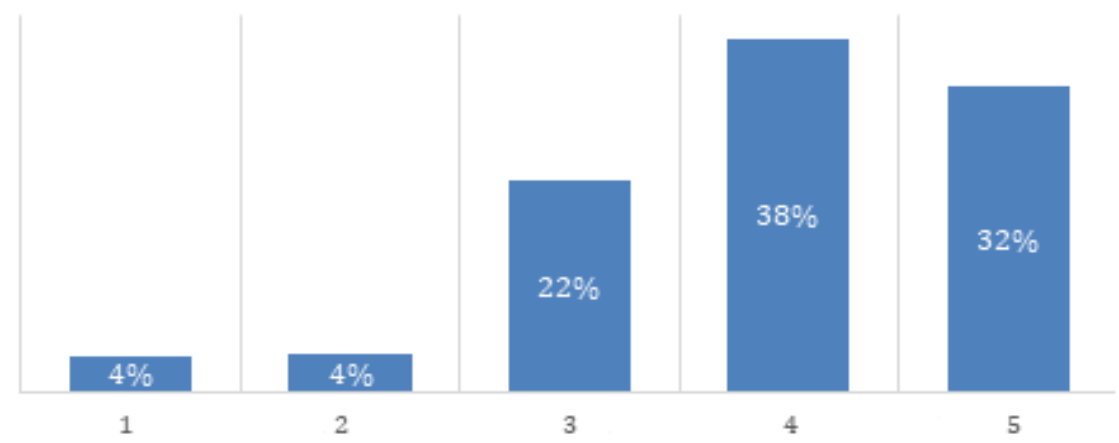

Fig.4. Student responses to the question "Do you think the flipped classroom has helped you to follow the subject better and not drop out?"

4. Do you think that the flipped classroom has helped you to understand the contents of the subject better?

Around $70 \%$ considered that it had helped them to understand the course contents (Fig. 5).

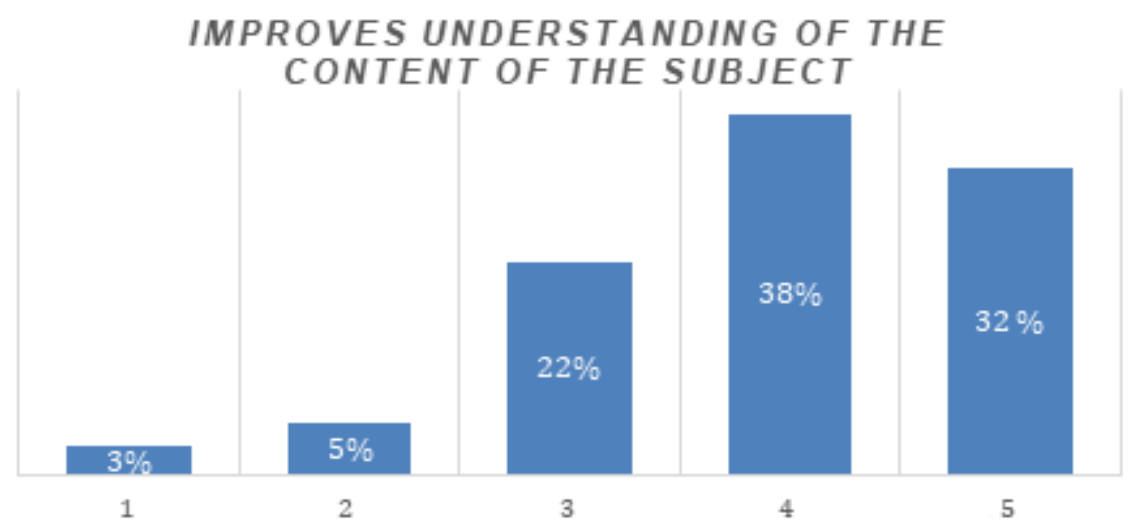

Fig. 5. Student responses to the question "Do you think that the flipped classroom has helped you to understand the contents of the subject better?"

\section{Do you think that this type of methodology favors autonomous learning?}

Approximately $77 \%$ considered that the methodology stimulated autonomous learning (Fig. 6).

\section{FAVOR AUTONOMOUS LEARNING}

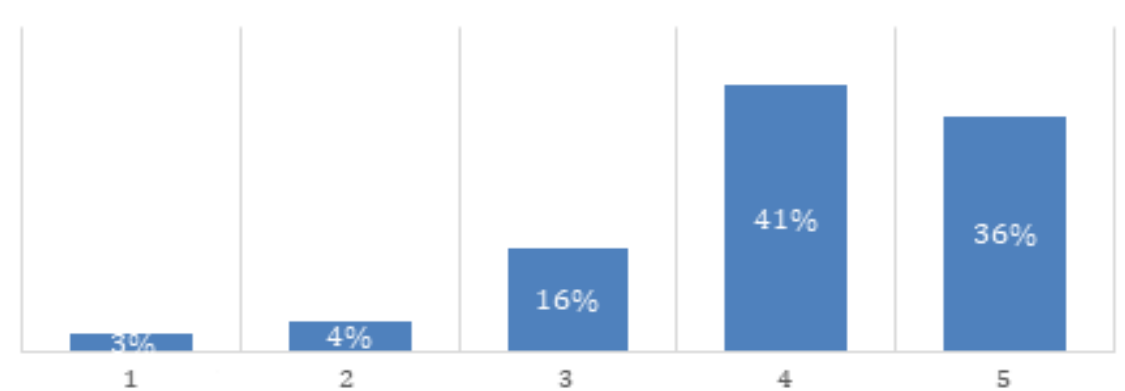

Fig.6. Student opinion on whether the flipped classroom favors autonomous learning 


\section{Other comments}

The students highlighted, as strengths of the project, the greater dynamism of the classes, which stimulated participation and improved the climate in the classroom as well as the teacher-student relationship, making the classes more enjoyable. The methodology was reported by students to help them assimilate course contents from the start.

The increased use of communication technologies (Kahoot, Socrative, Virtual Campus) was greatly appreciated, as it enabled the subjects to be more dynamic and to adapt the pace of learning to their own needs.

\subsection{Results from the point of view of the teachers involved in the project}

Teacher observed that class attendance and participation increased. The students came to class more motivated, and the drop-out rate was reduced.

\section{GENERAL ACCOUNTING}

Degree in Marketing and Market Research

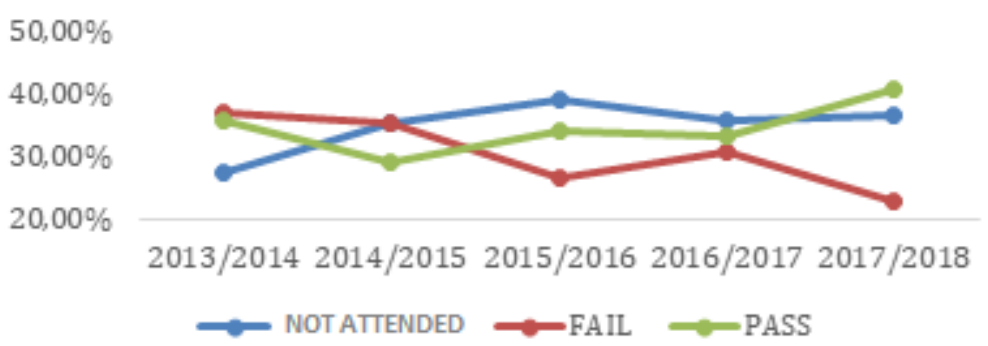

MANAGEMENT ACCOUNTING

Degree in Marketing and Market Research
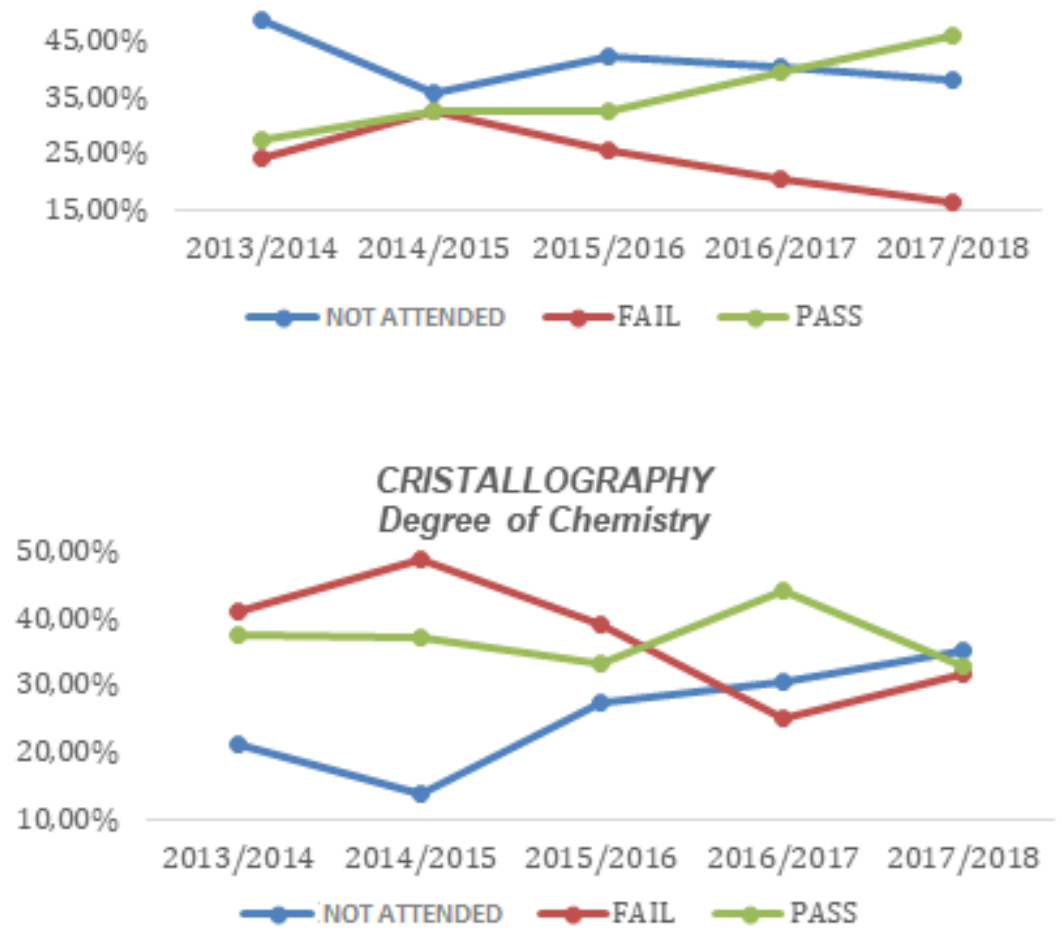


\section{MATHEMATICS FOR THE ECONOMY AND THE COMPANY}

Degree in Marketing and Market Research

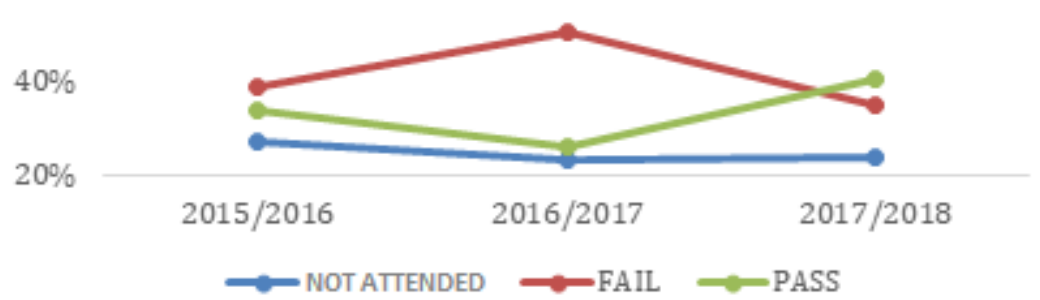

Fig. 7. Academic results in some subjects involved in the innovation project

The teachers felt that the classroom atmosphere was more relaxed. The students were more motivated (as also reported by the students themselves in the surveys).

The academic results since the implementation of the project can be compared with results from previous years. Figure 7 shows the percentages of students who were not attended, and who passed or failed a selection of the courses in which the flipped classroom was applied. The proportion of students "Not attended" and "Fail" decreased and the proportion of "Pass" students increased. We consider, though, that these comparisons are not definitive, since the students are different, but nevertheless we believe that they do indicate improvement (Fig. 7).

\section{CONCLUSIONS}

Students prefer the flipped classroom methodology to traditional classes. Likewise, they perceive that they learn more and better with this class dynamic.

The motivational factor is a key element to achieve significant learning. The flipped classroom generates interest in active learning and greater student autonomy.

Although we cannot reach definitive conclusions, as the students differed from one academic year to another and so from one methodology to the other, there are firm indications that academic performance has improved with the use of the flipped classroom.

One problem we have observed with this new mode of teaching, which has also been reflected in the comments of the students in the surveys, is that those students who do not perform the pre-class individual work (see Fig. 1), perhaps because they do not realize its importance, get lost in class and do not manage to advance through the course content. Therefore, we need to focus on this aspect of course delivery with the flipped classroom, and motivate students to engage fully with this new methodology from the beginning, so that they can become the owners of their own learning process and study at their own pace.

Implementing our project has taken a lot of effort and dedication. Teachers have to undertake training in this new methodology, the preparation of student materials, and the formulation of the questionnaires. However, in view of the academic results, the student satisfaction surveys and our own perception of interest and the progress of the classes, the endeavor has been worthwhile.

\section{REFERENCES}

[1] J.Bergmann,\& A.Sams, "Flip your classroom: Reach every student in every class every day". Washington, D.C., EEUU: International Society for Technology in Education. ISBN: 9781564843159, 2012

[2] J. F. Strayer, "How learning in an inverted classroom influences cooperation, innovation and task orientation," Learning Environments Research, vol. 15, pp. 171-193, 2012.

[3] J. L. Bishop and M. A. Verleger, "The flipped classroom: A survey of the research," in ASEE National Conference Proceedings, Atlanta, GA, pp. 1-18, 2013.

[4] O'Flaherty, J., \& Phillips, C. The use of flipped classrooms in higher education: a scoping review. The Internet and Higher Education, 25, 85-95, 2015. 
[5] A.P. Lopes \& F. Soares, "Perception and performance in a flipped Financial Mathematics classroom". The International Journal of Management Education, Elsevier, March 2018, vol: 16 (1), pp: 105-113. ISSN: 14728117. DOI: 10.1016/j.ijme.2018.01.001, 2018.

[6] L. Ogden and N. Shambaugh, "Best Teaching and Technology Practices for the Hybrid Flipped College Classroom," Handbook of Research on Innovative Pedagogies and Technologies for Online Learning in Higher Education, pp. 281-303, 2017.

[7] M. D. Hanus and J. Fox, "Assessing the effects of gamification in the classroom: A longitudinal study on intrinsic motivation, social comparison, satisfaction, effort, and academic performance," Comput. Educ., vol. 80, pp. 152-161, 2015.

[8] M. Prensky, "Digital Game-Based Learning," ACM Comput. Entertain., vol. 1, no. 1, 2003.

[9] S. Deterding, D. Dixon, R. Khaled, and L. Nacke, "From game design elements to gamefulness", in Proceedings of the 15th International Academic MindTrek Conference on Envisioning Future Media Environments - MindTrek '11, 2011, p. 9.

[10] K. M. Kapp, The gamification of learning and instruction: game-based methods and strategies for training and education. Pfeiffer, 2012.

[11] A. García-Barrera, "El aula inversa: cambiando la respuesta a las necesidades de los estudiantes". Avances en Supervisión Educativa. Revista de la Asociación de Inspectores de Educación de España, vol. 19, pp. 1-8, 2013.

[12] C.H.Crouch \& E. Mazur, "Peer instruction: Ten years of experience and results". American journal of physics, 69(9), 970-977, 2001

[13] A. King, "From sage on the stage to guide on the side". College teaching, 41(1), 30-35. 1993.

[14] Mazur, E. (1997) Peer instruction: A User's Manual Series in Educational Innovation. Upper Saddle River, NJ, EEUU: Prentice Hall, 1997

[15] J.O'Flaherty \& C.Phillips, "The use of flipped classrooms in higher education: A scoping review". The Internet and Higher Education, 25, 85-95, 2015.

[16] The Flipped Learning Global Initiative (FLGI) http://www. flglobal.org 2018 